\title{
A hyaluronidase from the Snake Venom of Agkistrodon Blomhoffii Ussurensis of Changbai Mountain: Isolation and Characterization
}

\author{
Dubo Zhong (Corresponding author) \\ Yunnan Product Quality Supervision and Testing Academe \\ No 23. Jiaochang East Road, Kunming 650223, Yunnan, China \\ Tel: 86-871-513-3113_E-mail: zhongdubo@yahoo.cn \\ Qingxiong Meng \\ Kunming University of Science and Technology \\ Kunming 650224, China \\ Junming Li, Yaqin Wang, Xiaohong Zhang, Shixing Wang \& Hongkun Zhu \\ Yunnan Product Quality Supervision and Testing Academe \\ No 23. Jiaochang East Road, Kunming 650223, Yunnan, China
}

\begin{abstract}
Snake venom is a complex mixture of protein and peptide toxins. Hyaluronidase a'spreading factor' has not been studied extensively in snake venom. In this paper, we describe the purification and characterization of a hyaluronidase from the snake venom of Agkistrodon blomhoffii ussurensis of Changbaimountain. Hyaluronidase has been purified by the successive chromatography on a DEAE-Sephadex A-25, on CM- Sephadex C-25 and on Sephadex G-75 columns on the basis of the purification method of thrombin-like enzyme (TLE). The molecular mass was found to be $35.0 \mathrm{kDa}$ by SDS-polyacrylamide gel electrophoresis. Hyaluronidase was 5.66 percent of the snake venom of Agkistrodon blomhoffii ussurensis of Changbai mountain, the activity of mass ( $\mathrm{u} / \mathrm{g}$ ) was 437218.5. The $\mathrm{pH}$ optimum for the enzyme was in the rang of 3.0-4.0 and 6.0-6.5,maximum activity was obtained at $37^{\circ} \mathrm{C}$, and the optimum concentration of $\mathrm{Na}^{+}(\mathrm{mol} / \mathrm{L})$ was in the rang of $0.3-3.0$, the $\mathrm{Km}$ for hyaluronidase, using hyaluronic acid as substrate, was $4.633 \times 10^{-3} \mathrm{mg} / \mathrm{ml}$. The hyaluronidase had not the inhibition effect to growth of the Hela cell and HepG-2 cell in vitro through the experiment.
\end{abstract}

Keywords: Agkistrodon blomhoffii ussurensis of Changbai mountain, Hyaluronidase, Hyaluronic acid

\section{Introduction}

Hyaluronidases are a ubiquitously expressed group of very dissimilar enzymes that naturally cleave hyaluronic acid (HA), a high molecular weight glycosaminoglycan, which is a major component of extracellular matrix (ECM) of vertebrates that connects protein filaments, collagen fibers and the connective tissue cells(Laurent T.C.,1989; Laurent T.C., 1992, pp.2397-2404). Some of these enzymes have the ability to degrade additional glycosaminoglycans, but at a slower rate(Frost G.I., 1996,pp.419-434).

Hyaluronidase has been considered as an invariant factor in the venoms of snakes, bees, scorpions, stonefish and lizards(Meyer K., 1971, pp.307-320; Kreil G., 1995, pp.1666-1669) and is popularly referred to as a 'spreading factor' as it facilitates easy diffusion of systemic toxins in to the circulation of the prey. Rapid hydrolysis of long linear megastructure of hyaluronan into fragments of varied molecular size drastically reduces the viscosity of the envenomed milieu favoring rapid diffusion of toxins into circulation which were otherwise diffused much slowly (Girish K.S., 2002, pp.105-110; Girish K.S., 2004, pp.193-202; Girish K.S., 2006, pp.1433-1440).

Kenzo Kudo and Anthony(Kudo K., 2001, pp.154-162) was comprehensive to report hyaluronidase activity from the venom of Agkistrodon contortrix contortrix(Southern Copperhead), on a Sephacryl S-200 HR column and CM-Sephadex C-25 column. The hyaluronidase's molecular weight is about $60 \mathrm{kD}$, the activity of mass $(\mathrm{u} / \mathrm{g})$ is 243000 , the optimal temperature is $37{ }^{\circ} \mathrm{C}$, the optimum $\mathrm{pH}$ is 6.0 , the optimum concentration of $\mathrm{Na}^{+}(\mathrm{mol} / \mathrm{L})$ is in the rang of $0.3-3.0$. But the concentration of hyaluronidase in the venom is very small, from $500 \mathrm{mg}$ crude venom only $0.3 \mathrm{mg}$ of purified hyaluronidase could be obtained. 
The 70 percent of thrombin-like enzyme (TLE) was purified from the snake venom of Agkistrodon blomhoffii ussurensis of Changbai mountain, the first purification was DEAE-Sephadex A-25 chromatography, the penetrated liquid through DEAE-Sephadex A-25 column as waste, but the waste has hyaluronidase. In this paper, hyaluronidase has been purified by the successive chromatography on a CM-Sephadex C-25 and on Sephadex G-75 columns on the basis of the purification method of thrombin-like enzyme (TLE). We have not found the report of purification of hyaluronidase from the snake venom of Agkistrodon blomhoffii ussurensis of Changbai mountain.

\section{Materials and methods}

\subsection{Materials}

Lyophilized crude venom from Agkistrodon blomhoffii ussurensis of Changbai mountain was provided by pharmaceutical limited company of Kaitai, Hubei province of china; DEAE-Sephadex A-25, CM-Sephadex C-25, Sephadex G-75 was from Pharmacia; bovine testicular hyaluronidase was from Sigma; HA was from biological limited company of Jiangyin, Jiangsu province of China; heal cell and hepG-2 cell was provided by Neural Molecular Biology Laboratory, Faculty of Life Science and Technology, Kunming university of science and technology; All other chemicals and reagents were of the first grade commercially available.

\subsection{Methods}

\subsubsection{Venom}

The Lyophilized crude venom from Agkistrodon blomhoffii ussurensis of Changbai mountain was macerated and dissolved in phosphate buffer $20 \mathrm{mM}, \mathrm{pH} 7.6$, and immediately centrifuged at 3000rpm for $10 \mathrm{~min}$. Venom was stored at $-20^{\circ} \mathrm{C}$ until use.

\subsubsection{DEAE- Sephadex A-25 column chromatography}

The crude venom was loaded on a DEAE- Sephadex A-25 column $(2.5 \times 30 \mathrm{~cm})$ previously equilibrated with $20 \mathrm{mM}$ tris-Hcl buffer, $\mathrm{pH} 7.6$, and flowed with the same buffer at a flow rate of $48 \mathrm{ml} / \mathrm{h}$, collected the penetrated liquid through DEAE-Sephadex A-25 column within 6 hours. The collected liquid was lyophilized to powder, the mass of powder is $0.3 \mathrm{~g}$.

\subsubsection{CM-Sephadex C-25 column chromatography}

The powder of 2.2.2 was loaded on a CM-Sephadex C-25 column $(1.6 \times 20 \mathrm{~cm})$ previously equilibrated with $20 \mathrm{mM}$ phosphate buffer,pH 6.4, and flowed with the same buffer. Column was eluted stepwise using same buffer containing $\mathrm{NaCl}$ of $0-1000 \mathrm{mM}$. Fractionation was carried out at room temperature at a flow rate of 30 $\mathrm{ml} / \mathrm{h}$ and fractions were collected, the collected fractions was Lyophilized to powder.

\subsubsection{Sephadex G-75 column chromatography}

The Lyophilized fractions of 2.2.3 was loaded on a Sephadex G-75 column $(1 \times 40 \mathrm{~cm})$ previously equilibrated with $20 \mathrm{mM}$ phosphate buffer,pH 6.4, and flowed with the same buffer. Fractionation was carried out at room temperature at a flow rate of $30 \mathrm{ml} / \mathrm{h}$ and fractions were collected, the collected fractions was Lyophilized to powder.

\subsubsection{Hyaluronidase activity}

The hyaluronidase activity was determined turbidimetrically by the method of Ferrante(Kudo K., 2001, pp.154-162; Ferrante ND, 1956, pp.303-306). Aliquots of $50 \mathrm{ml}$ of the enzyme solution were added to $70 \mathrm{mg}$ of hyaluronan in $0.45 \mathrm{ml}$ of $0.2 \mathrm{M}$ sodium acetate buffer, $\mathrm{pH} 6.0$, containing $0.15 \mathrm{M} \mathrm{NaCl}$. The mixture was incubated at $37^{\circ} \mathrm{C}$ for $15 \mathrm{~min}$, and then the reactions were terminated by the addition of $1 \mathrm{ml}$ of $2.5 \%$ hexadecyltrimethylammonium bromide in $2 \% \mathrm{NaOH}$ solution. After $5 \mathrm{~min}$, the optical density of each sample was read by spectrophotometer at $400 \mathrm{~nm}$ and then blank-corrected. All assays were performed in duplicate. Bovine testes hyaluronidase was also used for comparison. One unit is defined as the amount of enzyme that will cause the same turbidity reduction as 1.0 unit of international standard preparation.

\subsubsection{SDS-polyacrylamide gel electrophoresis}

SDS-PAGE (15\%) was carried out according tothe method of Laemmli(Laemmli U.K., 1970, pp.680-685). Molecular weight standards from 116 to $14.4 \mathrm{kDa}$ were used.Electrophoresis was carried out using Tris (25 mM), glycine $(192 \mathrm{mM})$ and SDS $(0.1 \%)$ for $3 \mathrm{~h}$ at $90 \mathrm{~V}$ at room temperature. After electrophoresis, gel was stained with $0.1 \%$ Coomassie brilliant blue R-250 for detection of the protein bands and destained with $25 \%$ ethanol and $10 \%$ acetic acid. 


\subsection{7 $\mathrm{pH}$ and temperature kinetics and effect of $\mathrm{NaCl}$ on enzyme activity}

For determination of the optimum $\mathrm{pH}$ for enzyme activity, $0.2 \mathrm{M}$ sodium acetate buffer containing $0.15 \mathrm{M} \mathrm{NaCl}$ was used. The sodium acetate solution has buffer capacity from 3 to 11. For the optimum temperature study, the enzyme activity at various temperatures was measured under the standard assay conditions. For the optimum $\mathrm{NaCl}$ concentration study, sodium acetate buffer, $\mathrm{pH}$ 6.0, containing various $\mathrm{NaCl}$ concentrations was used.

\subsubsection{Protein estimation}

Protein concentration was determined according to the method of Lowry et al. using bovine serum albumin (BSA) as standard.

\subsubsection{The activity of anti-tumour in vitro}

The activity of anti-tumour in vitro was determined turbidimetrically by the method of MTT, and the inhibition ratio of hyaluronidase to growth of heal cell and hepG-2 cell in vitro was calculated by Graphad Prism 5.0 software and Excel software(Pauwels R, 1988, pp.309-321; Park JG, 1987, pp.5875-5879).

\section{Results}

\subsection{Purification of hyaluronidase}

A three-step protocol was standardized for hyaluronidase purification. The first step involved the DEAESephadex A-25 chromatography on the basis of the purification method of thrombin-like enzyme (TLE) (Fig. 1A), the penetrated liquid was collected and lyophilized to powder. The second step involved the CM-Sephadex C-25 chromatography and resolved into four peak of protein. The second peak containing hyaluronidase activity was eluted with a linear gradient of $\mathrm{NaCl}$ (Fig. 1B). The third step involved the Sephadex G-75gel filtration chromatography and resolved into two peak of protein, the second peak containing hyaluronidase activity (Fig.1C).

SDS-PAGE showed that the enzyme migrated as a single band, and the molecular weight of the hyaluronidase was about $35 \mathrm{kDa}$ (Fig. 2). Fig. 3 are the standard turbidimetrical curve of HA and hyaluronidas. Hyaluronidase was 5.66 percent of the snake venom of Agkistrodon blomhoffii ussurensis of Changbai mountain. A summary of the purification procedure is given in (Table 1). The enzyme was purified to 76.6 -fold with a yield of 4.33-fold, having a specific activity of $4.37 \times 10^{5} \mathrm{u} / \mathrm{g}$ of protein. We can found there is the inhibitor of hyaluronidase from Table 1.The inhibitor was acidic substance.

The $\mathrm{pH}$ activity profile of purified hyaluronidase was determined in a $\mathrm{pH}$ range from 3 to 11 using sodium acetate buffer. The enzyme had two optimal $\mathrm{pH}$ range:3.0-4.0;6.0-6.5 (Fig. 4A). Degradation effect of HA is maximal in the $\mathrm{pH}$ range from 3 to 4 (Hokputsa S, 2003, pp.111-117; Severian Dumitriu, 1998, 313-335), so mangabe hyaluronidase have the maximal activity in the $\mathrm{pH}$ range from 3.0 to 4.0. The influence of temperature on hyaluronidase activity was determined between 4 and $60{ }^{\circ} \mathrm{C}$ at $\mathrm{pH} 6.0$. The optimal temperature for hyaluronidase activity was $37{ }^{\circ} \mathrm{C}$ and the activity decreased significantly apart from $37{ }^{\circ} \mathrm{C}$ (Fig. 4B). The enzyme activity was greatly influenced by sodium ions, and it reached its maximal activity in the range from 0.2 to $3.2 \mathrm{M}$ sodium ions (Fig. $4 \mathrm{C}$ ). The $\mathrm{Km}\left(1.09 \times 10^{-3} \mathrm{mg} / \mathrm{ml}\right)$ values were calculated from the fig of Hanes of the hyaluronidase with the substrate hyaluronic acid(Xu, X, 1982, pp.973-981) (Fig. 5).

\subsection{The activity of anti-tumour in vitro}

The hyaluronidase of the snake venom of Agkistrodon blomhoffii ussurensis of Changbai mountain had not activity of anti-tumour to growth of heal cell and hepG-2 cell in in vitro(Fig. 6).

\section{Discussion}

Pathophysiological mechanism of sanke venom in duced tissue damage and spreading facilitated diffusion of systemic toxins is currently gaining importance. Venom contains mixture of toxins and envenomation-induced effects are due to synergistic effects of these toxins. Metalloprotease and hyaluronidases are the main components involved in local tissue damage and gravitational spreading of the venom. The pathology involves the degradation of proteins and glycosaminoglycans in the extracellular matrix (ECM) surrounding the blood vessels and capillaries (Xu, X, 1982, pp.973-981; Baramova, E.N., 1989, pp. 63-71; Maruyama, M., 1992, pp.1387-1397; Girish K.S., 2002, pp.105-110).

In this study with the snake venom of Agkistrodon blomhoffii ussurensis of Changbai mountain, we found that three-step fractionation on DEAE- Sephadex A-25, columnCM-Sephadex C-25 colum and Sephadex G-75 column resulted in the purification of a protein with hyaluronidase activity on the basis of the purification method of thrombin-like enzyme (TLE). The final yield of $5.66 \%$ (protein by weight) and of 4.34 -fold of 
76.6-fold purified hyaluronidas will signify the difficulty associated in working with the enzyme. There is the inhibitor of hyaluronidase, and the inhibitor was acidic substance.

SDS-polyacrylamide gel electrophores is showed that hyaluronidase purified from the snake venom of Agkistrodon blomhoffii ussurensis of Changbai Mountain as a single band with an estimated molecular mass of $35 \mathrm{kDa}$.

The optimal $\mathrm{pH}$ for the enzyme activity was diffrent from that found for hyaluronidase from a variety of snake venom. There were two range: 3.0-4.0;6.0-6.5. Degradation effect of HA is maximal in the $\mathrm{pH}$ range from 3 to 4(Sanya Hokputsa, 2003, pp.111-117), so mangabe hyaluronidase have the maximal activity in the $\mathrm{pH}$ range from 3.0 to 4.0. The optimum temperature was found to be $37^{\circ} \mathrm{C}$ at $\mathrm{pH} 6.0$, and it is in agreement with hyaluronidase from Agkistrodon contortrix contortrix(Southern Copperhead)( Xu xun, 1983, p.680-681).The enzyme activity was greatly influenced by sodium ions, and it reached its maximal activity in the range from 0.2 to $3.2 \mathrm{M}$ sodium ions.

The purified hyaluronidase from the snake venom of Agkistrodon blomhoffii ussurensis of Changbai mountain showed Michaelis kinetics with hyaluronic acid as substrate. The $\mathrm{Km}$ of $1.09 \times 10^{-3} \mathrm{mg} / \mathrm{ml}$ indicates that the enzyme has comparatively high affinity for hyaluronic acid compared with other hyaluronidases. This value was substantially lower than the reported for Agkistrodon acutus $\left(6.2 \times 10^{-3} \mathrm{mg} / \mathrm{ml}\right)$.

There are two diametrically opposite views about the role of hyaluronidase on the activity of anti-tumour. Some studies think that the expression increases of HA in the serum and ECM have a relationship with the progress and transfer of malignant tumor (Lee J Y, 2000, p.581; Zhang L, 1995, p.428). Excessive synthesis of HA promote the growth of cancer cells (Kosaki R, 1999, p.1141), and hyaluronidase inhibits malignant tumor by decomposing HA, so hyaluronidase is taken as the products of tumor inhibiting genes(Csoka AB, 2001, p.499; De Maeyer E, 1992, p.657).However,other researches discovered that hyaluronidase have a stimulation to growth, invade and transfer of tumor cells(Lin G, 2001, p.95). We found the hyaluronidase had not the inhibition effect to growth of the Hela cell and HepG-2 cell in vitro through the experiment. So we can principally determinant that the hyaluronidase has not effect to growth of the tumour cells, it will have effect to the tumour cells only in the human body and with the HA. But whether it has the promotion effects or the inhibition effects should be researched later.

In conclusion, this study presents the first purification of a hyaluronidase from the snake venom of Agkistrodon blomhoffii ussurensis of Changbai Mountain. This enzyme exhibited high affinity for hyaluronic acid. Further structural and functional analyses might provide an insight for the better understanding of the role.

\section{References}

Baramova, E.N., Shannon, J.D., Bjarnason, J.B., Fox, J.W. (1989). Degradation of extracellular matrix proteins by hemorrhagic metalloproteinases. Arch. Biochem. Biophys, 275, 63-71.

Csoka AB, Frost GI, Stern R. (2001). The six hyaluronidase likegenes in the human and mouse genomes. Matrix Biol, 20 (8), 499.

De Maeyer E, De Maeyer2Guignard J. (1992). The growth rate of two transplantable murine tumors, 3LL lung carcinoma and B16F10melanoma, is influenced by Hyal21, a locus deter2 mining hyaluronidase levels and polymorphism. Int $J$ Cancer, 51(4), 657.

Ferrante ND, Buford L. Nichols, Patricia V. Donnelly, Giovanni Neri, Ruzica Hrgovcic, Robert K. Berglund. (1956). Turbidimetric measurement of acid mucopolysaccharides and hyaluronidase activity. J. Biol. Chem, 220, 303-306.

Frost G.I., Csoka, T., Stern, R. (1996). The hyaluronidase: a chemical biological and clinical overview. Trends Glycosc.Glycotechnol, 8, 419-434.

Girish K.S., Jagadeesha D.K., Rajeev K.B., Kemparaju K. (2002). Snake venom hyaluronidase: an evidence for isoforms and extracellular matrix degradation. Mol. Cell. Biochem, 240, 105-110.

Girish K.S., Jagadeesha D.K., Rajeev K.B., Kemparaju, K. (2002). Snake venom hyaluronidase: an evidence for isoforms and extracellular matrix degradation. Mol. Cell. Biochem, 240, 105-110.

Girish K.S., Shashidharamurthy R., Nagaraju S., Gowda T.V., Kemparaju K. (2004). Isolation and characterization of hyaluronidase a 'spreading factor' from Indian cobra (Naja naja) venom. Biochimie, 86, 193-202.

Girish, K.S., Kemparaju, K. (2006). Inhibition of Naja naja venom hyaluronidase: role in the management of 
poisonousbite. Life Sci, 78 (13), 1433-1440.

Hokputsa S, Jumel K, A1 exander C. (2003). Hydrodynamic characterization of chemically degraded hyaluronic acid. Carbohydrate Polymers, 52,111-117.

Kosaki R, Watanage K, Yamaguchi Y. (1999). Overproduction of HA by expression of the HA synthasse Has2 enhancesanchorage2independent growth and tumorigenicity. Cancer Res, 59, 1141.

Kreil G. (1995). Hyaluronidases - a group of neglected enzymes. Protein Sci, 4, 1666-1669.

Kudo K., Anthony T. Tu. (2001). Characterization of hyaluronidase isolated from Agkistrodon contortrix contortrix (Southern copperhead) venom. Arch. Biochem. Biophys, 386, 154-162.

Laemmli U.K. (1970). Cleavage of structural proteins during the assembly of the head of bacteriophage T4. Nature, 227, 680-685.

Laurent T.C. (1989). The Biology of Hyaluronan. Wiley, NewYork.

Laurent T.C., Fraser, J.R.E. (1992). Hyaluronan. FASEB J, 6, 2397-2404.

Lee J Y, Spicer AP. (2000). Hyaluronan:a mulifunictional.Megadalton stealth mole-cule. Curr Opin Cell Biol, 12, 581.

Lin G, Stern R. (2001). Plasma hyaluronidase ( Hyal21) promotes tumor cell cycling, Cancer Lett, 163(1), 95.

Maruyama, M., Sugiki, M., Yoshida, E., Shimaya, K., Mihara, H. (1992). Broad substrate specificity of snake venom fibrinolytic enzymes: possible role in hemorrhage. Toxicon, 30, 1387-1397.

Meyer K. (1971). Hyaluronidases. In: 3rd ed. Boyer, P.D. (Ed.), In the Enzymes, vol. V.-Academic press, New York:pp. 307-320.

Park JG, Kramer BS, Steinberg SM, Carmichael J, Collins JM, Minna JD, Gazdar AF. (1987). Chemosensitivity Testing of Human Colorectal Carcinoma Cell Lines Using a Tetrazolium-based Colorimetric Assay. Cancer Res, 47, 5875-5879.

Pauwels R, Balzarini J, Baba M, Snoeck R, Schols D, Herdewijn P, Desmyter J, De Clercq E. (1988). Rapid and automated tetrazolium-based colorimetric assay for the detection of anti-HIV compounds. Virol Methods, 20, 309-321.

Sanya Hokputsa, Kornelia Jumel, Catherine Alexander, Stephen E. Harding. (2003). Hydrodynamic characterisation of chemically degraded hyaluronic acid. Carbohydrate Polymers, 52(1): 111-117.

Severian Dumitriu. (1998). Polysaccharides: Structural Diversity and Functional Versatility. Marcel Dekker, NewYork. 313-335.

Xu xun,Wang xianshun, Xi xingtuan. (1983). The study of snake venom of Agkistrodon acutus II : Isolation and characterization of hyaluronidase. ACTA Biochemical et Biophysica Sinica, 6(15), 680-681.

Xu, X., Wang, X., Xi, X., Liu, J., Huang, J., Lu, Z. (1982). Purification and partial characterization of hyaluronidase from five pace snake (Agkistrodon acutus) venom. Toxicon, 20,973-981.

Zhang L, Underhill CB, Chen L. (1995). Hyaluronan on the surface of tumor cells is correlated with metastatic behavior. Cancer Res, 55,428.

Table 1. Summary of purification of hyaluronidase from the snake venom of Agkistrodon blomhoffii ussurensis of Changbai mountain

\begin{tabular}{|l|l|l|l|l|l|}
\hline Purification step & $\begin{array}{l}\text { Total protein } \\
(\mathrm{mg})\end{array}$ & $\begin{array}{l}\text { Total activity } \\
(\mathrm{u})\end{array}$ & $\begin{array}{l}\text { Specific } \\
\text { activity } \\
(\mathrm{u} / \mathrm{g})\end{array}$ & $\begin{array}{l}\text { Purification } \\
(\text { fold })\end{array}$ & Yield (fold) \\
\hline Crude venom & 800 & $4.57 \times 10^{3}$ & $5.71 \times 10^{3}$ & 1 & 1 \\
\hline $\begin{array}{l}\text { DEAE-Sephadex } \\
\text { A-25 }\end{array}$ & 300 & $3.64 \times 10^{4}$ & $1.21 \times 10^{5}$ & 21.2 & 7.96 \\
\hline Sephadex G-75 & 45.3 & $1.98 \times 10^{4}$ & $4.37 \times 10^{5}$ & 76.6 & 4.34 \\
\hline
\end{tabular}


A

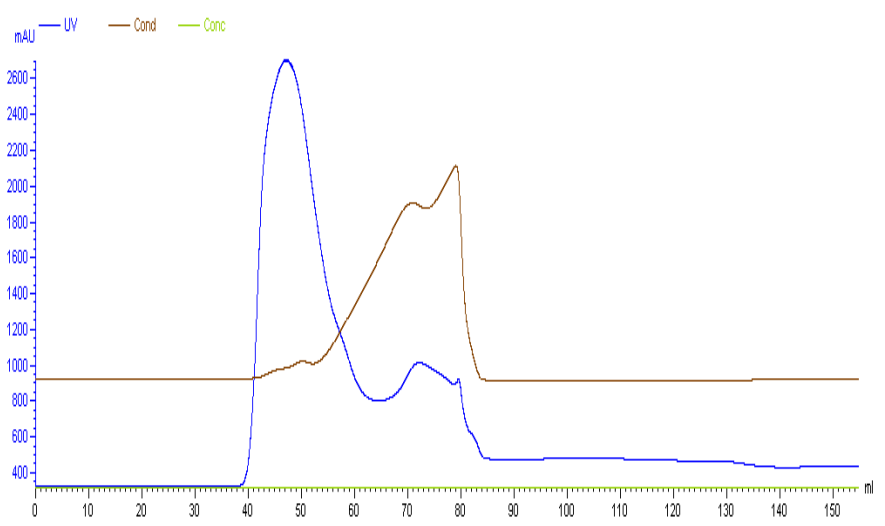

B

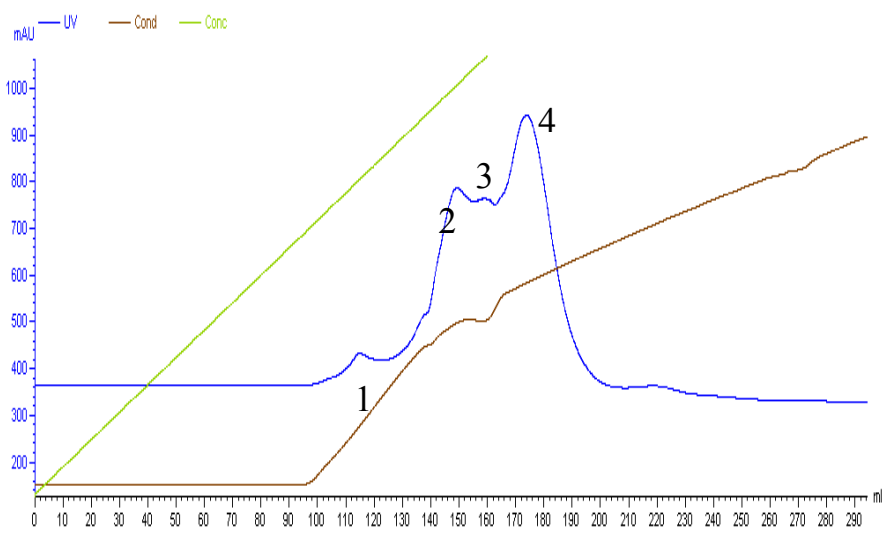

$\mathrm{C}$

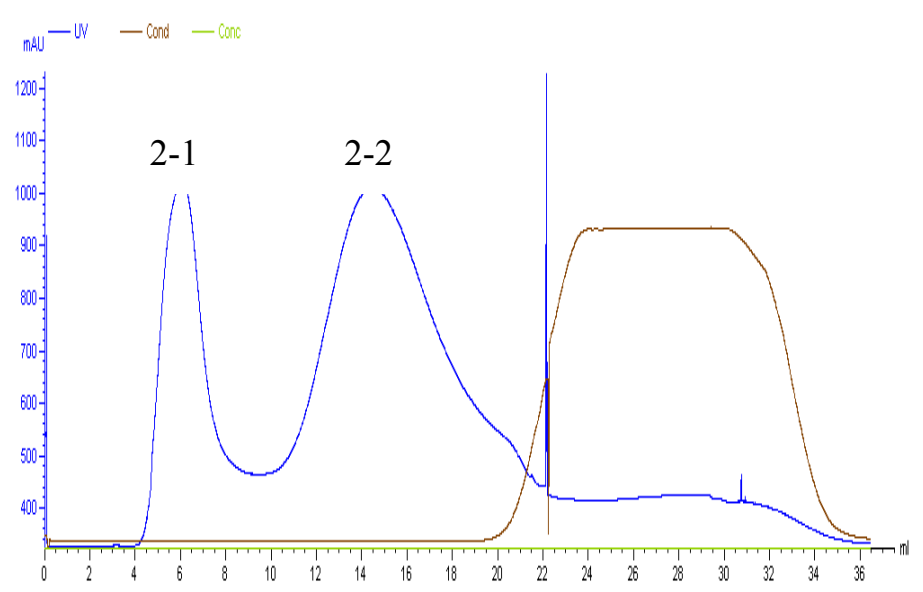

Figure 1. Isolation of hyaluronidase from the snake venom of Agkistrodon blomhoffii ussurensis of Changbai mountain.(A) Elution profile from DEAE-Sephadex A-25 chromatography.The column $(2.5 \times 30 \mathrm{~cm})$ was eluted with $20 \mathrm{mM}$ tris-Hcl buffer,pH 7.6 at a flow rate of $48 \mathrm{ml} / \mathrm{h}$, and $45 \mathrm{ml}$ fractions were collected.Protein elution was monitored at $280 \mathrm{~nm}$. The collected fractions was concentrated and applied onto CM-Sephadex C-25 column for further fractionation. (B)Elution profile from CM-Sephadex C-25 column chromatography.The column $(1.6 \times 20 \mathrm{~cm})$ was equilibrated with $20 \mathrm{mM}$ phosphate buffer, $\mathrm{pH} 6.0$,at a flow rate of $30 \mathrm{ml} / \mathrm{h}$. The column was washed with the same buffer and eluted with a linear gradiet of $0-1.0 \mathrm{M} \mathrm{NaCl}$, resolved into four peak of protein.The second peak containing hyaluronidase activity,and was concentrated and applied onto Sephadex G-75 column for further fractionation. (C) Elution profile from Sephadex G-75 chromatography.The column $(1 \times 40 \mathrm{~cm})$ was eluted with $20 \mathrm{mM}$ phosphate buffer, $\mathrm{pH} 6.0$, containing at a flow rate of $30 \mathrm{ml} / \mathrm{h}$, resolved into two peak of protein,the first peak containing hyaluronidase activity.Protein elution was monitored at $280 \mathrm{~nm}$ 


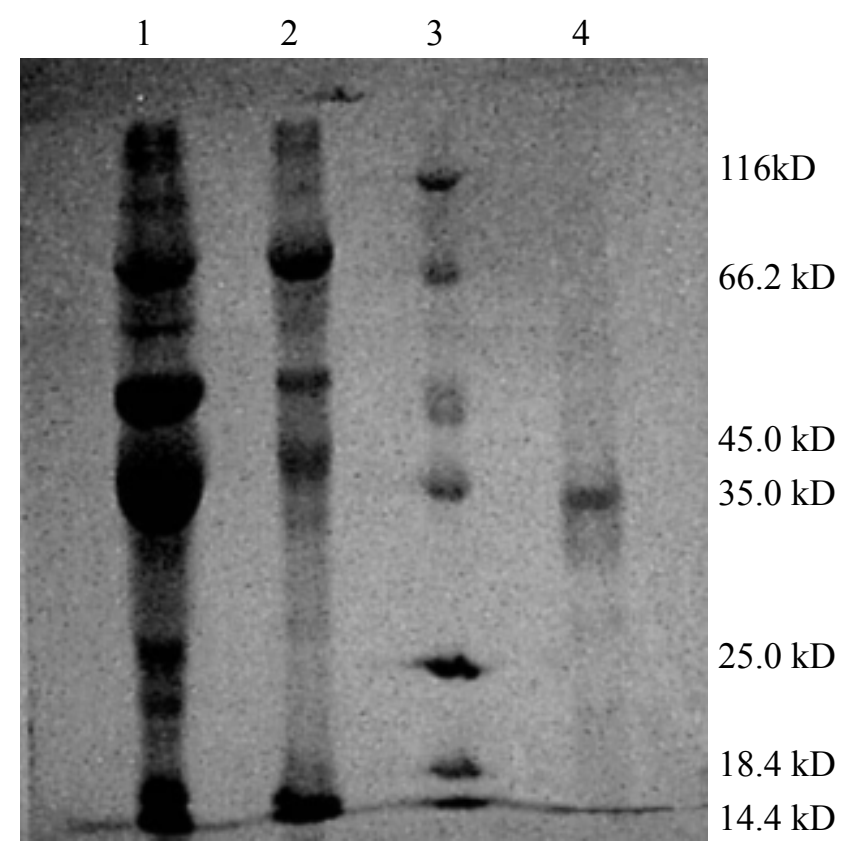

Figure 2. SDS-PAGE of the purified hyaluronidase.(Lane 1) Crude the snake venom of Agkistrodon blomhoffii ussurensis of Changbai mountain. (Lane 2) Purified enzyme after DEAE- Sephadex A-25 chromatography.

(Lane 3) Molecular weight markers. (Lane 4) Purified hyaluronidase 
A

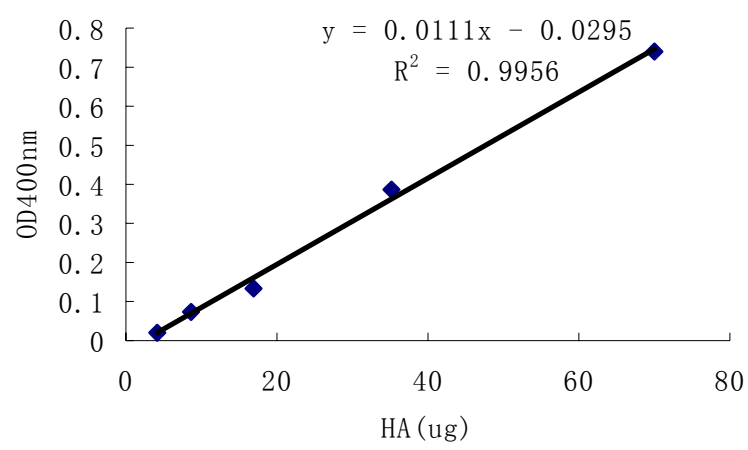

B

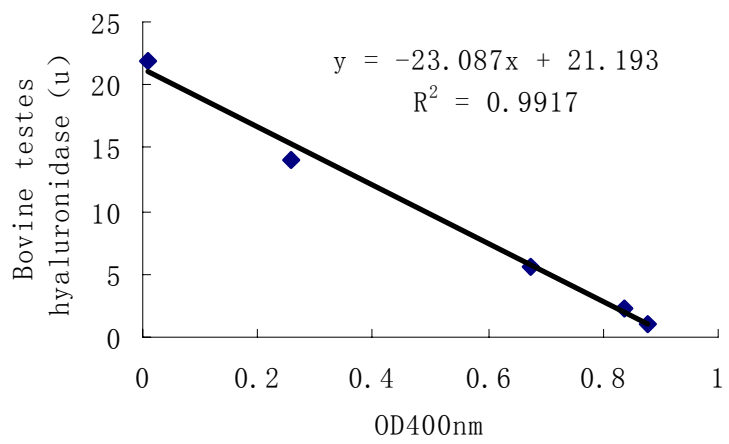

Figure 3. Determination of enzyme activity of the purified hyaluronidase from the snake venom of Agkistrodon blomhoffii ussurensis of Changbai mountain.(A) Different mass of hyaluronan in $0.45 \mathrm{ml}$ of $0.2 \mathrm{M}$ sodium acetate buffer, $\mathrm{pH} 6.0$,containing $0.15 \mathrm{MNaCl}$ was incubated at $37^{\circ} \mathrm{C}$ for $15 \mathrm{~min}$, and then the reactions were terminated by the addition of $1 \mathrm{ml}$ of $2.5 \%$ hexadecyltrimethylammonium bromide in $2 \% \mathrm{NaOH}$ solution.After 5 min,the optical density of each sample was read by spectrophotometer at $400 \mathrm{~nm}$ and then blank-corrected.All assays were performed in duplicate.(B) Aliquots of $50 \mathrm{ml}$ of the different concentration of bovine testes hyaluronidase solution were added to $70 \mathrm{mg}$ of hyaluronan in $0.45 \mathrm{ml}$ of $0.2 \mathrm{M}$ sodium acetate buffer, $\mathrm{pH}$ 6.0 , containing $0.15 \mathrm{MnaCl}$. The mixture was incubated at $37^{\circ} \mathrm{C}$ for $15 \mathrm{~min}$, and then the reactions were terminated by the addition of $1 \mathrm{ml}$ of $2.5 \%$ hexadecyltrimethylammonium bromide in $2 \% \mathrm{NaOH}$ solution. After 5 min,the optical density of each sample was read by spectrophotometer at $400 \mathrm{~nm}$ and then blank-corrected. All assays were performed in duplicate 
A

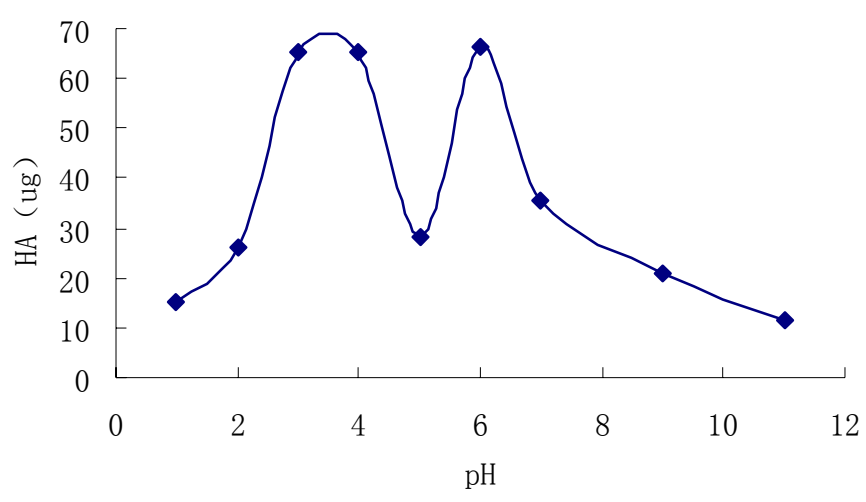

B

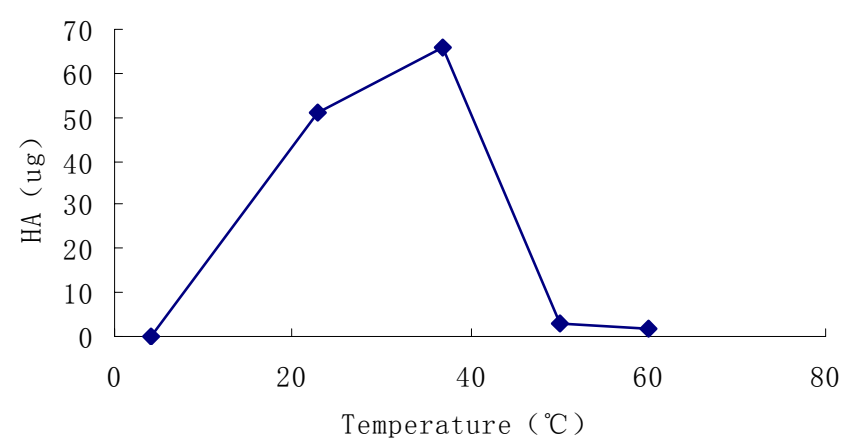

$\mathrm{C}$

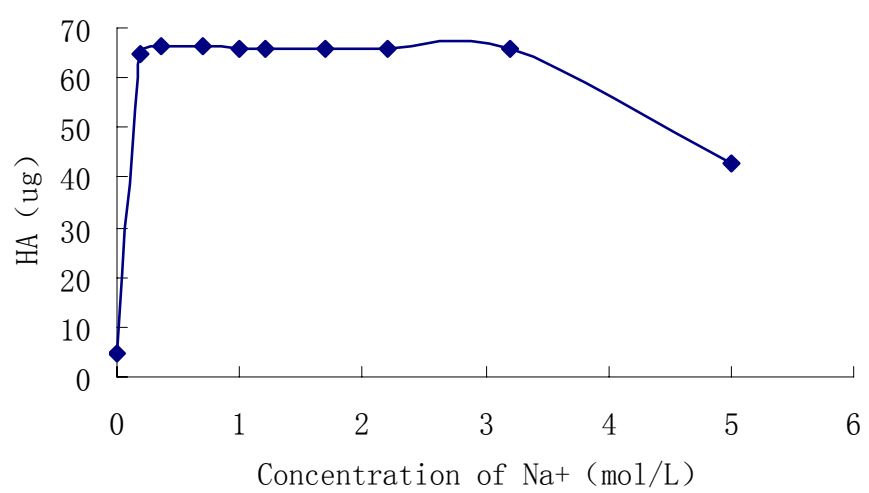

Figure 4. The effect of $\mathrm{pH}(\mathrm{A})$,temperature (B), and $\mathrm{NaCl}$ concentration 


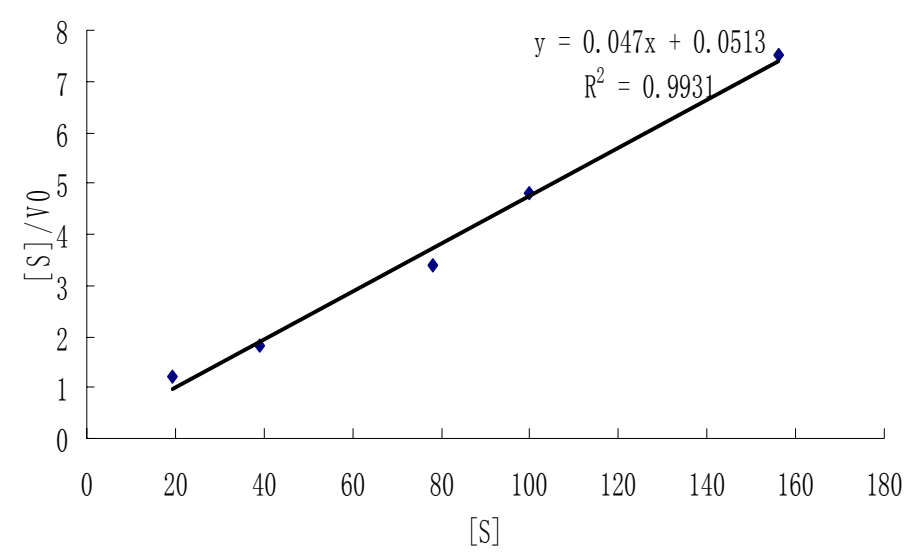

Figure 5. Fig of Hanes of the hyaluronidase with the substrate hyaluronic acid.Experiments were performed at $37^{\circ} \mathrm{C}$ and $\mathrm{pH} 6.0$

A

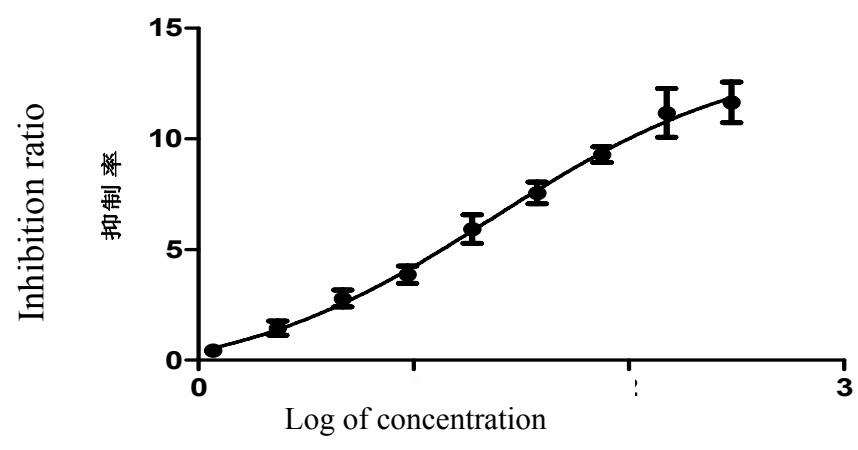

B

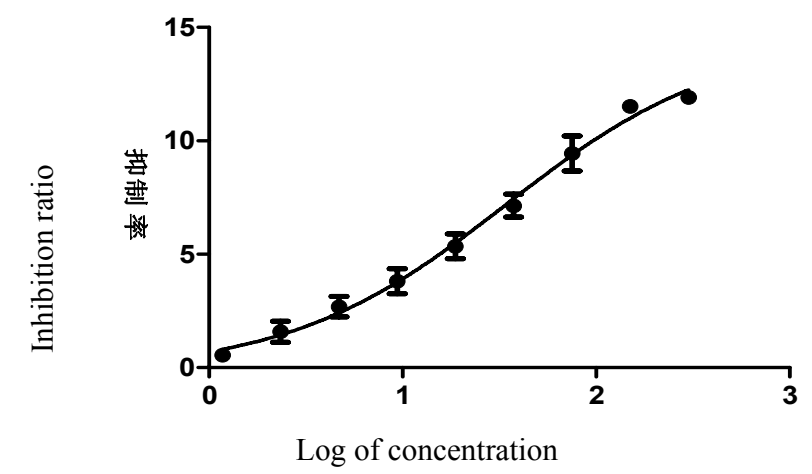

Figure 6. The activity of hyaluronidase of anti-tumour in vitro.(A)The effect of different concentration of hyaluronidase to growth of heal cell in vitro.(B) The effect of different concentration of hyaluronidase to growth of hepG-2 cell in vitro 